\title{
GOOD FINANCE: INTEGRATION OF ETHICS AND SHARIAH IN ISLAMIC FINANCE
}

\author{
Hafas Furqani ${ }^{1 *}$, Mohamad Akram Laldin ${ }^{2 *}$, Ratna Mulyany ${ }^{3 *}$
}

\footnotetext{
* Affiliation:

${ }^{1}$ Faculty of Islamic

Economics and Business, Ar-Raniry State Islamic University, Banda Aceh, Indonesia. hafasf@gmail. $\underline{\mathrm{com}}$

${ }^{2}$ International Shariah Research Academy for Islamic Finance (ISRA), Malaysia.

${ }^{3}$ Department of Accounting, Syiahkuala University, Banda Aceh, Indonesia.
}

\begin{abstract}
:
Islamic Financial industry is moving towards the global integration. There is a considerable acceptance of Islamic financial practices across the globe. Islamic finance is viewed positively as an attractive financial system that could be adopted in modern context. One of the reasons for this acceptance could be due to its ethical promises. Islamic finance is perceived as an ethical based finance that is operating with a set of good ethics in financial dealings. With that ethical back up as the underlying principles in financial activities, there is wide expectation that it could offer a different perspective and approach in finance and a coherent perspective for understanding real economic problems faced by human being and hence could elegantly solve the crisis as regularly faced in the conventional financial system. Islamic finance is developed with the aim of capturing the moral high ground of banking and financial practices in an increasingly volatile world by offering a financial philosophy based on the triumph of ethics and dealing with customers in a more humanistic approach for the betterment of society. In this regard, the moral mastery is not only expected to be the hallmark of Islamic financial professionalism, but it is also desired to be naturally integrated in the system and its practitioners. Islamic finance aims to achieve a fair wealth circulation in society, fair and transparent financial dealings and justice in micro and macro dimension. The paper attempts to discuss the concept of ethics in Islamic finance, its basis, principles and objectives in the contemporary world.
\end{abstract}

Keywords: Islamic finance, ethics, good finance, Shari'ah compliance, maqāṣid al-Shari’ah.

\section{INTRODUCTION}

The Islamic finance industry is moving towards global integration. There is a general interest and acceptance of Islamic financial practices worldwide and clear recognition that Islamic finance represents a viable financial system that could be adopted in the modern context. One of the reasons for this acceptance could be due to the underlying ethical premises of Islamic finance. 
In March 2009, the Vatican, in its official newspaper L'Osservatore Romano, said: "The ethical principles on which Islamic finance is based may bring banks closer to their clients and to the true spirit which should mark every financial service" (Totaro, Bloomberg, 2009).

This statement provides a clear message that it is the ethical values in Islamic finance that essentially attract audiences to look into it and participate in its operations. With the ethical back up as its underlying principles, there is wide expectation that it could offer a different perspective and approach to finance that takes into account real economic problems faced by society and could solve the recurrent crises confronting the conventional financial system.

The ethical premises of Islamic finance are derived from the foundations of Islam that provide guidance as to how a good financial system should work. These value propositions, among others, are the following:

- Islamic banking and finance is based on the Principles of Shari'ah (ahkām al-Shar'iyyah) which set the rules and regulations applicable in financial dealings and aims to achieve the goals of Shari'ah (maqaîid al-Shari'ah) which establish the direction of financial activities.

- Islamic banking and finance promises growth in accordance with ethics and moral commitment, social responsibility and financial stability.

Islamic banking and finance offers a variety of contracts and allows dynamism and flexibility in product development and innovation.

This ethical concern to strengthening business ethics should be elaborated, defined and developed as a guide to market players for setting the proper behavioural framework that should direct financial activities. This paper aims at elaborating this ethical concern in the context of Islamic financial practices. The idea is that moral mastery should not only be expected to be the hallmark of Islamic financial transactions, but it should also be well integrated within the Islamic financial system and imbued within its practitioners.

\section{ISLAMIC FINANCE AND ETHICAL CONCERN}

In the recent decades, there has been a growing interest in the issue of ethics and finance from the public, academics, investors and businesses. The calculation of costs and benefits in term of financial profit as a reliable guide to determine what is harmful and beneficial is viewed as insufficient in deciding what is good and bad.

In fact, many have claims that profit maximization fueled by thrift and greediness has caused the financial crisis. Oskari Juurikkala (2010:27) for example argues the greed of financial institutions to get profit irrespective of moral values has caused the crisis. Financial instruments called derivatives have been used in unethical ways to fool regulators and personal gain at the expense of public interest.

The global finance situation has triggered mankind to rethink the relationship of ethics and good finance. Some of other reasons on the need for ethical consciousness in financial dealings and the integration of ethics within the domain of finance are as the following.

\section{Systemic Concern}

To achieve the goal of having a solid financial system, ethics, rules and regulations are inseparable elements that guide market players in their interaction within the system. 
Unfortunately, in conventional finance, ethical consideration is treated as an exogenous variable to the system. Ethical exogenism implies that finance philosophy and practice is independent of value propositions and interventions. Professionalism in the field of finance is thus defined and measured in a mechanistic perspective of profit maximisation. All stakeholders operating within the system seek to achieve higher and more profits than be concerned about the impact of their actions on society and the environment. Even the elements of deregulation and liberalisation in financial markets have been promoted in an attempt to attract more participants and investment in the finance industry, with little concern of the importance of ethics and morality.

Since ethics is assumed not to form part of the financial system, it becomes incapable in affecting the parameters for establishing a good social order within the system. Eventually, when the gap widens, a dysfunction in the financial system occurs. A typical case is the example of recurring crises in the modern financial system which, for some, is triggered by unethical motives and actions. They are said to represent a moral failure instead of a system failure. The cause is the unethical behavior of market players, who attracted by greed and profit maximisation, justify their highly speculative practices and have transformed financial dealings into a casino, rather than an industry that empowers people and stimulates productive activities and development.

Hence, it is necessary for ethics to be included in finance as one of its important dimensions in establishing a sound financial system. In an integral ethical system, financial institutions would not be viewed as mere intermediaries but as enabling institutions that can empower people and companies to pursue and achieve their goals. This would systematically reshape the industry and guide it towards a proper direction (Lynch, 1994: x).

\section{Behavioral Concern}

The disclosure of unethical conduct in numerous important branches of business and industry has triggered global consciousness on the need to have an ethically-based finance. The frequency of mass media reports on instances of frauds, insider trading and the manipulations of books has seemingly increased in the last decades. Recent examples include the auditing and accounting scandals that well-known and well-respected US firms like Enron, WorldCom and Xerox have been involved in. Many such cases have been reported in several parts of the world. The impact of shocks, scandals and crises - in the form of lawsuits, embarrassing protests, revelations, denial of capital, threats, sanction of regulation-are said to "have often, if regrettably, achieved more progress in raising ethical behaviour than has moral suasion” (Davies, 2003: 303).

The integration of ethics within the domain of economics and finance should be attempted by cultivating good behaviour and establishing a positive environment for good corporate practices. This could be instituted in the form of ethical codes of conduct to be abided by practitioners in the finance industry. Ethical conduct could also be promoted by:

- Organizing the finance profession under professional bodies which would instil their own code of ethics and ensure the ethical behaviour of their members.

- Establishing appropriate rules and control processes at the level of financial institutions that would promote transparency and disclosure of relevant information, while impeding excessive or unfair actions. 
- Developing a culture of accountability and honesty, especially through prudent and exemplary leadership.

This would result in achieving greater efficiency in financial practices along with stability in the financial system. In addition, it would avoid moral degeneration, conflict and social tensions that arise from unfair or inhuman financial practices.

Profit and ethics, should not be viewed as something irreconcilable. Profit is lawful and legitimate if it is derived from legitimate means. It also has a moral purpose whereby profit could be used for developing human potential, providing relief from suffering, opening up new opportunities in technology and other fields of human endeavor (Lynch, 1994: 3)

\section{Good Finance}

The consciousness to bring back ethics into finance is also led by the strong desire from society to have what is called 'good finance' or 'ethical finance'. An ethical mode of finance would be concerned of the implications created as a result of financial transactions. Its role is to create a positive impact on the economy, the environment and society. To this end, profit making is viewed not only for private gain but also within the perspective of social impact (Ahmed, 2012: 5).

Lack of ethical concern in financial dealings would result in erosion in trust and confidence in financial institutions, in the products and services, and in the individuals involved in the financial transactions. Lack of ethical focus can lead to consequences that would tarnish the image of financial services and the system as a whole. Furthermore, according to a study by Lynch (1994: 3-4), such situation would lead to (1) poor image that will result in a financial institution being used by its customers as a last resort rather than as a first choice, (2) degradation of moral values that will manifest itself in the attitudes and behavior of employees such as involvement in corruption, lack of transparency, avoiding fairness and honesty, (3) poor service to customers and society at large, (4) failed financial system as has been discussed earlier, the origins of the financial crisis started with a moral crisis arising from greed, selfishness, fraud and other unethical conduct, and finally (5) lack of ethical focus would also lead to a corrupt society. This is because a good society is built upon ethical values where the stakeholders have full ethical and moral commitment.

\section{THE BASIS OF ETHICS IN ISLAMIC FINANCE}

Having said the importance of ethics in financial system and practices, the next question is what is ethics? from where ethical propositions can be derived? and what kind of ethics is needed to properly guide financial activities especially in the case of Islamic finance?

\section{What is Ethics?}

Ethics (also commonly known as morals and values) is a system of moral principles which defines what is good for individuals and society. Ethics deals with the question of what is good and bad, right and wrong, and correct and false. 
In Islam, ethics is termed as akhlāq (khuluq in plural). It is defined as standards of right and wrong that prescribe what humans ought to do as taught by the Qur'an, and demonstrated in the exemplary life (actions and words) of the Prophet (s.a.w). Umaruddin (2003: 66) in his book The Ethical Philosophy of al-Ghazali defines Islamic ethics as "nothing but the body of injunction laid down in the Qur'an for the practical conduct of life and fully exemplified in the practice of the Prophet Muhammad s.a.w".

The ethical dimension covers a wide spectrum - from preconceiving how decisions or choices are made, to their implementation through one's action, until the practical consequences of that action are seen. Issues that are morally significant usually have to do with relationships, agreements between parties, intentions and possible outcomes (Thompson, 2010: 4).

Ethics discusses morality and provides guidance on moral choice. This is done by distilling the proclaimed values and norms of individuals, enabling them to identify courses of action which will enhance the moral quality of human behaviour (Lynch, 1994: 43).

In this perspective, three basic frameworks can be used to clarify our understanding of 'what' ethics is, namely:

- Principled conscience - helping us decide what is right by reference to principles such as fairness, courage, integrity, transparency, kindness, and others.

- Social conscience - helping us decide what is right by considering the consequences, both good and bad, of our actions on others.

- Rule compliance - telling us what is right by considering the rule of law.

The dimension of ethics is not confined to the normative realm. Ethics is also practically oriented in the sense that its effects can only be felt when it is applied in practice. Therefore, having a correct and comprehensive perspective of ethics is important as its application would bring impacts on human life.

\section{Source of Ethics in Islamic Finance}

Ethics can either be secular-based or religious-based. Secular ethics, as argued by Naqvi (2003: 4) is autonomously determined, independent of religious beliefs. Its source is western ethical philosophy, generally understood to imply a search for rational understanding of the principles of human conduct. Religious-based ethics on the other hand is derived from scripture and divine laws that guide society.

The source of ethics in Islamic finance is based on religious values founded on the teachings in the Qur'ān and the Sunnah (Prophet's way) - the two prime sources of reference in Islam. Those guidance and value-patterns from the Qur'an and the Sunnah serve as an ethical compass for finance and adopted as an ethical framework that guide Islamic financial practices.

Islamic ethics is embodied in the religious commands and prohibitions related to commercial and financial activities as outlined in the concept of Shari'ah. Shari'ah provides ways and means for a complete and comprehensive way of life that includes faith and practices (aqidah), personal behaviour and ethics (akhlaq), man-to-God worship (ibadat) as well as man-to-man relations through business and social transactions (mua'malat). Shari'ah also provides orientation on the objectives to be pursued in Islamic finance, namely to realise benefits (mașlahah) and prevent harms (mafsadah) for individuals and in social life. 
In its practice, Islamic financial ethics calls for the interplay between ethics and financial transactions. Financial aspect is put forward as part of the larger Islamic ethical system since the financial aspect in Islam is considered part of 'religion' whereby all business activities, wealth creation, economic development, wealth distribution, human welfare are also considered the 'business of religion'.

\section{ETHICS AND FINANCIAL DEALINGS}

Ethics is an inescapable element in Islamic financial transactions that would determine the parameters for establishing a good social order within the system is upheld. Islamic finance in this regard is very much aware of the moral failure of unethical motives and actions in financial practices that could lead to financial crises. Islamic ethics application should be seen in all Islamic financial activities, from product structuring, marketing and all dimensions when Islamic finance institutions deal with their customer. The ethical commitment represents the true meaning of Shari'ah compliance.

\section{Ethics and Financial Contracts}

In the spirit of achieving benefits (mașlahah) for human beings through wealth creation and augmentation, the Shari'ah has legislated various transactions and contracts. Those contracts, called as nominate contracts ('uqud al-musamma), are legislated with detailed rulings by Shari'ah aims to ensure a fair transition whereby all parties involved in a contract would benefit from the transactions and nobody would be marginalized, exploited or cheated.

In general, Islamic nominate contracts related to economic transactions are classified into three main categories, namely exchange (mu'awdat), partnership (ishtirak), and gratuitous (tabarru'at).

- Exchange contracts ('uqud al-mu'awadat) include simple spot sales (buyu'); sales that create debt, such as deferred payment sales in the form of forward sale (bay' salam and bay'istisna'), leasing contract (ijarah), and reward for successful completion of a job (ju'alah).

- Partnership contracts ('uqud al-Ishtirak) are ones in which one party assigns work/ capital/obligation to another party (or parties). These contracts include agency (wakalah), partnerships (sharikah) contracts in the forms of profit and loss sharing (mudarabah and musharakah), assignment (hawalah), and pledge or mortgage (rahn).

- Gratuitous contracts ('uqud al-tabarru'at) whereby ownership or possession (right of use) is transferred without consideration or compensation. Gratuitous contracts include loans ('ariyah and qard), deposits (wadi'ah), gifts (hibah) and guarantee/ security (daman or kafalah).

Every contract is designed to serve a 'particular purpose' (muqtada al- 'aqd) as defined by Shari'ah which reflects its nature, function and purpose. The purpose of a contract is an integral part of ethics of that contract that must be followed and remain clear of manipulations that would distort its primary purpose (Kamali, 2012: 622). 
The creation of Islamic banking products using particular contracts should essentially take care of the particular purpose of the contract and not merely the technical-formalities of pillars (arkan al-'aqd), conditions (shurut al-'aqd) and attributes of the contract (awsaf al'aqd). The muqtada al- 'aqd reflects the combination of all these factors into one solid form of contract (i.e., the combination of form and substance of contract, reflecting the external and internal intentions of the parties involved) (Laldin and Furqani, 2013).

To distort the Shari' ah-ordained purpose of a contract through questionable stipulations, or through recourse to legal tricks and stratagems (hiyal), becomes problematic, and as Kamali (2012: 623) observes, if allowed unchecked would naturally effect the ethical propriety of the contract in question.

This spirit marks the Islamic approach in commercial (financial) dealings that takes in consideration not only the form but also the substance (including ethics) of the transactions. While certain formalities and substantive elements are essential for a transaction to become legally binding on the parties, this should be done through mutual agreement that brings about mutual consent and satisfaction (rida) (al-Baqarah [2]:282). Therefore, along with the approval of various contractual facilities and the emphasis on fulfilment of contractual obligations, Islamic law also provides various ways to remove contractual obligation in situations of unavoidable difficulties and necessities (Islam, 1998: 368).

\section{Ethics and the Meaning of Shari'ah Compliance}

Having that perspective, it is clear that law and ethics is inseparable in Islamic financial practices. The adherence to the legal principle and rules of Shari'ah (usually called as Shari'ah compliance) is not meant as merely complying with the Islamic legal principles in its structural forms, but also, in satisfying the substantive spirits of ethical and moral imperatives.

This is because law and ethics, from the Shari'ah perspective is inseparable and should not be made contradictory in developing Islamic finance, as the Qur'anic worldview recognizes no distinction between legal imperatives and moral obligations.

The legal compliant structure of Islamic financial products should essentially reflect the spirit of Islamic values that represent the hallmark of financial dealings among the contracting parties to gain mutual benefit or reach a win-win situation. Islamic financial contracts would not recognize any financial dealing with no solid ethical ground that would lead one party to gain from the transaction and the other party to lose.

Many commands and prohibitions in Shari'h should therefore be understood from the perspectives of both legal and ethical grounds. The prohibition of riba (usury), for example, should be understood as not merely the prohibition of any excess charge on a sum loaned, but also a moral prohibition of exploitation of man by man in financial transactions or the derivation of a gain without any effort. Likewise, an ethical perspective of riba prohibition would result in upholding the spirit of trust between customers/investors and fund managers where both parties would cooperate for their mutual benefits (Fazlurrahman, 1985).

Ethics would thus broaden the perspective of Shari'ah compliance from mere compliance to legal forms in product structures to also include the commitment to ethical principles and values. The value propositions that Islam promotes in financial activities should 
be incorporated in practices in accordance with the correct application of contracts ('aqd) in financial products. Therefore, Shari'ah scholars (advisors in Islamic financial institutions) should also play a role as guardians of business ethics and not merely as legal advisors for a Shari'ah-compliant product structure (Nienhaus, 2011).

\section{ETHICS AND THE OBJECTIVES OF SHARI'AH IN ISLAMIC FINANCE}

To have a fair, just and good financial transaction that would benefit all parties is the objectives to be realized in the perspective of Shari' ah. Shari' ah has set the goals and objectives of the Shari'ah upon which the Shari'ah is established and to which all actions of human being are directed in the concept of maqasid al-Shari'ah. They are standards and criteria, values and guidance rooted in divine revelation (wahy) to be applied in solving the problems that confront mankind and in guiding the direction of life.

The prime ethical objective of Shari'ah (maqāṣid al-Shari'ah) is establishing and realizing mașlahah (benefits) and eliminating mafsadah (harms) in human life. Shariah in all its rulings aims at realizing mașlahah that would facilitate benefits, fairness, justice and goodness and removing mafsadah that would implicate to the harms, injustice, exploitation, and dispute in financial products and transactions (Al-Qaradawi, 2007).

The discussion on the maqāșid al-Sharī'ah in Islamic finance is framed in terms of protection of wealth (hifz al-mal) as mentioned by al-Ghazali in his classification of mașlahah. This approach is justified as the subject matter of finance and the function of financial institutions as financial intermediaries is basically how to allocate resources from the surplus sector (capital providers) to the deficit sector (capital users) so that wealth is smoothly circulated and human welfare is realised. This, however, should be looked at from a broader perspective to include ethical and moral messages instead of mere economic interest (Laldin and Furqani, 2013).

Based on the general objective of acquiring benefit (mașlahah) and preventing harm (mafsadah), specific and particular objectives (maqasid khașah) in the enactment of financial laws and its application in financial practices could be derived as the following:

- The objective of wealth circulation and development

Ccommercial and financial activities is viewed positively in Shari' ah as mechanisms to circulate wealth among all the sections of society. Wealth should not be concentrated in the hands of a few (among the rich/the 'have' of society). Instead it has to go into all segments of society (Qur'an, al-Hashr [59]: 7).

In line with that spirit, wealth should be employed in productive activities. The funds should not be wasted or left idle (Qur'an, al-Tawbah [9]:34) or managed unprofessionally (Qur'an, al-Nisa' [4]:5). In fact, any funds/wealth that are not employed will be "penalized" through zakah (alms giving), which will gradually reduce the volume of wealth and put it back into circulation. Zakah is a mechanism that necessarily keeps wealth in continuous circulation.

- The objective of fair and transparent financial dealings

Shari'ah guarantees the freedom of contract and freedom in crafting the contract. The basic principle is the permissibility (ibahah) in commercial and financial transactions so long does not contradict with the law of Islam. Nevertheless, this freedom is to be used within an atmosphere of fairness, equity, justice and high morality. Any contract stipulated and agreed by both parties should be respected and enforced (Qur'an, al-Maidah [5]:1). The application of the Shari'ah in financial 
practices should therefore not result in injury, harm or difficulties to the contracting parties or the public at large. This is in line with the intent of the Shari'ah which aims to create a positive atmosphere in banking and commercial transactions, instituting the principles of trust, brotherhood, cooperation and mutual benefit among stakeholders.

Transparent and fair dealings are considered among the main objectives of the Shari'ah in financial transactions and activities. The Shari'ah, in this regard, aims at creating an equal and fair transactional atmosphere and at protecting the parties against exploitation or imbalance between their reciprocal rights and obligations.

- The objective of justice in micro and macro dimension (al- 'adalah)

The above objective of wealth circulation is a macro goal of the Shari'ah while the maqāssid of fair and transparent financial practices are related to micro goals of the Shari'ah in transactional instruments and mechanisms. The maqsad of justice embraces both micro and macro dimensions. This maqsad is related to the desire of having a just order of society as well as just dealings among individuals in financial transactions. Kamali (2012: 22) observes that justice and fairness are the hallmark in commercial contracts. If a contract proves to be an instrument of injustice, such a contract must be set aside, and justice, which is the goal and maqsad of the Lawgiver, must be given priority over considerations of conformity to an untenable contract.

The above objectives of Shariah reflect ethical principles in transactions that Islamic finance aims to realize in order to develop a good finance. The objectives of Shari'ah integrate law and ethics in Islamic finance which necessitates us to redefine the meaning of Shariah compliance as not merely a legal compliance, but also ethical commitment. Islamic finance would be more meaningful if it pursues ethical transactions and practices that would bring more impact to society rather than limiting to legal-compliance transactions which might sideline ethical principles through various legal stratagems (hiyal) which make the contract valid in its appearance but problematic in its substance.

\section{CONCLUSION}

As a conclusion, Islamic finance is concerned with values and ethics that would determine a good finance. Ethics in Islamic finance is derived from the religious sources, namely the Qur'an and Sunnah. Sharī'ah is not only about Islamic rulings or legal principles, but also about values and ethics. Any Sharī'ah prohibitions in financial activities aim at removing mafsadah (harms) which might inflict upon parties in transaction. Those prohibited actions are actually negative actions in an ethical point of view. Likewise, any Sharī'ah injunctions aim at ensuring benefits (mașlahah) would be realized. Those are positive values that would ensure fairness, justice and benevolence in a transaction.

The ethical spirit is the hallmark of Islamic financial practices and one of the determinations of Sharī'ah compliance. Ethics annihilation in financial practice might lead to meaningless financial practices. Islamic financial institutions should really ensure that ethics and values are in place to ensure a real Sharī'ah compliant practice of Islamic finance. Having those perspectives, Islamic finance is able to be contributing to the creation of a good finance for a good society. 


\section{REFERENCES}

Ahmed, H. (2012). Defining Ethics in Islamic finance: Looking Beyond Legality. Available at <URL: http://conference.qfis.edu.qa/app/media/290>

Al-Qaradawi, Y. (2007). Dirasah fi Fiqh Maqāșid al-Shari'ah: Bayn al-Maqāṣid al-Kulliyyah wa al-Nusus al-Juz'iyyah. Cairo: Dar al-Shuruq.

Davies, R. (2003). The Business Community: Social Responsibility and Corporate Values, in Dunning, J. H. (Ed.). Making Globalization Good: The Moral Challenges of Global Capitalism. (301-319). Oxford: Oxford University Press.

Fazlurrahman. (1985). Law and Ethics in Islam. In Richard G. Hovannisian (ed.), Ethics in Islam: Ninth Giorgio Levi Della Vida Biennial Conference (pp. 3-15). Malibu, California: Undena Publications.

Islam, M. W. (1998). Dissolution of Contract in Islamic law. Arab Law Quarterly. 13 (4), 336368.

Juurikkala, O. (2010). The Greed of Financial Institutions Caused the Crisis. In Noah Berlatsky (ed.), The Global Financial Crisis, p. 27-30. USA: Greenhaven Press.

Kamali, M. H. (2012). Ethics and Finance: Perspectives of the Shari'ah and Its Higher Objectives (Maqasid). Islam and Civilisational Renewal. 3 (4), 619-627.

Laldin, M. A., and Furqani, H. (2013). "Developing Islamic Finance in the Framework fo Maqasid al-Shari'ah: Understanding the Ends (maqasid) and the Means (Wasa'il)". International Journal of Islamic and Middle Eastern Finance and Management, Vol. 6, No. 4, pp. 278-289.

Lynch, James J. (1994). Banking and Finance: Managing the Moral Dimension. England: Gresham Books.

Nienhaus, V. (2011). Islamic Finance Ethics and Shariah Law in the Aftermath of the Crisis: Concept and Practice of Shari'ah Compliant Finance. Ethical Perspective. 18 (4): 591623.

Thompson, M. (2010). Understand Ethics. UK: Hodder Headline.

Totaro,L.(2009,March4).VaticanSaysIslamicFinanceMayHelpWesternBanksin Crisis.retrieved from http://www.bloomberg.com/apps/news?pid=newsarchive\&sid=aOsOLE8uiNOg.

\section{ACKNOWLEDGEMENT}

An earlier version of this paper has been presented at the 6th Islamic Economic System Conference (iECONS 2015), Krabi, Thailand, 29-30 September 2015, organized by USIM (University Science Islam Malaysia) and IRTI (Islamic Research and Training Institute) of Islamic Development Bank. 